\title{
Electro-Mechanical Stresses on Bacillus Atrophaeus Bacterial Spore Germination Induced by Pulsed Electric Fields
}

\section{Xing Qiu}

Hong Kong University of Science and Technology

Wen Jie WU ( $\nabla$ ee_wwjaa@hotmail.com )

The Chinese University of Hong Kong https://orcid.org/0000-0002-2175-5053

\section{Original article}

Keywords: pulsed electric fields (PEF), electro-mechanical stresses, electric forces, compression effect, spore germination, QW's EM-spore model

Posted Date: November 19th, 2020

DOI: https://doi.org/10.21203/rs.3.rs-107370/v1

License: (c) (i) This work is licensed under a Creative Commons Attribution 4.0 International License.

Read Full License 


\section{Abstract}

In this work, the electro-mechanical stresses induced by pulsed electric fields (PEF) on bacterial spore germination was modeled and empirically tested using Bacillus atrophaeus spores. Specifically, a new model, termed as Qiu-Wu's electro-mechanical (QW's EM) spore model, was derived to analyze the effect of electro-mechanical stresses on spores subjected under electric fields. A non-linear inverse relationship was found between electric fields and thickness change of spore coat. SEM, $\mathrm{pH}$, hydrophobicity and electrochemical measurements were implemented for verification of the model. PEF-treated spores germinated with a faster rate and a higher degree of homogeneity. The longer the treatment time, the better the homogeneity. The speed of dipicolinic acid (DPA) release was around $20 \%$ faster in PEF-treated samples, while the peak intensity of terbium-DPA from PEF-treated samples was up to $80 \%$ lower. Theoretical analysis and empirical results were consistent to show that PEF introduces electromechanical stresses to expedite spore germination. The significance and impact of this study is obvious: bacterial spore is implicated in food spoilage and foodborne diseases primarily via the process of germination, and PEF technology has been introduced to inactivate microorganisms in food.

Understanding the mechanism of germination under PEF can provide deep understanding for inactivation of foodborne pathogens and better food preservation methods.

\section{Full Text}

This preprint is available for download as a PDF.

\section{Tables}

Table 1 Germination parameters monitored by phase-contrast microscopy

\begin{tabular}{|c|c|c|c|c|c|c|c|}
\hline \multirow{2}{*}{$\begin{array}{l}\text { Germination } \\
\text { Parameters }\end{array}$} & \multicolumn{7}{|c|}{ Treatment Condition } \\
\hline & $\begin{array}{l}\text { Non-PEF } \\
\text { treatment }\end{array}$ & $\begin{array}{l}7.5 \mathrm{kV} \\
\mathrm{cm}^{-1}, 1 \\
\text { pulse in } \\
\text { DI water }\end{array}$ & $\begin{array}{l}7.5 \mathrm{kV} \mathrm{cm}^{-} \\
1,50 \\
\text { pulses in } \\
\text { DI water }\end{array}$ & $\begin{array}{l}7.5 \mathrm{kV} \\
\mathrm{cm}^{-1}, 1 \\
\text { pulse in } \\
\text { saline }\end{array}$ & $\begin{array}{l}7.5 \mathrm{kV} \\
\mathrm{cm}^{-1}, 50 \\
\text { pulses in } \\
\text { saline }\end{array}$ & $\begin{array}{l}15 \mathrm{kV} \\
\mathrm{cm}^{-1}, 1 \\
\text { pulse in } \\
\text { saline }\end{array}$ & $\begin{array}{l}15 \mathrm{kV} \\
\mathrm{cm}^{-1}, 50 \\
\text { pulses in } \\
\text { saline }\end{array}$ \\
\hline $\begin{array}{l}\text { Mean of } \\
T_{\text {lag }}(\mathrm{min})\end{array}$ & 12.4 & 8.3 & 11.2 & 5.2 & 1.3 & 6.8 & 2.3 \\
\hline $\begin{array}{l}\text { Distribution } \\
\text { of } T_{\text {lag }}(\mathrm{min})\end{array}$ & 13.8 & 7.6 & 11.1 & 5.2 & 1.6 & 2.5 & 2.2 \\
\hline $\begin{array}{l}\Delta T_{\text {release }} \\
(\mathrm{min})\end{array}$ & $2.5 \pm 0.9$ & $2.3 \pm 0.6$ & $2.3 \pm 0.7$ & $2.1 \pm 0.5$ & $2.0 \pm 0.4$ & $2.3 \pm 0.6$ & $2.4 \pm 0.8$ \\
\hline
\end{tabular}


Figures
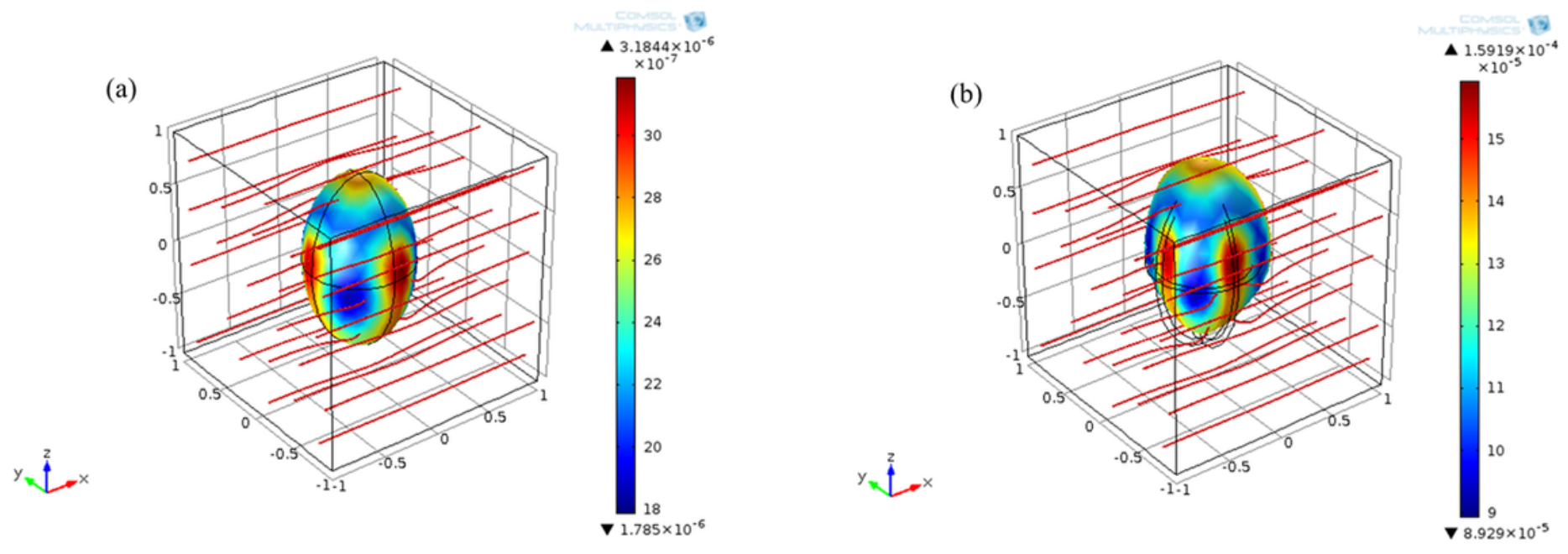

Figure 1

Spore simulation during a time-course of $50 \mathrm{~ms}$. Surface stress and morphology after PEF treatment at 1 pulse (a) and 50 pulses (b). 

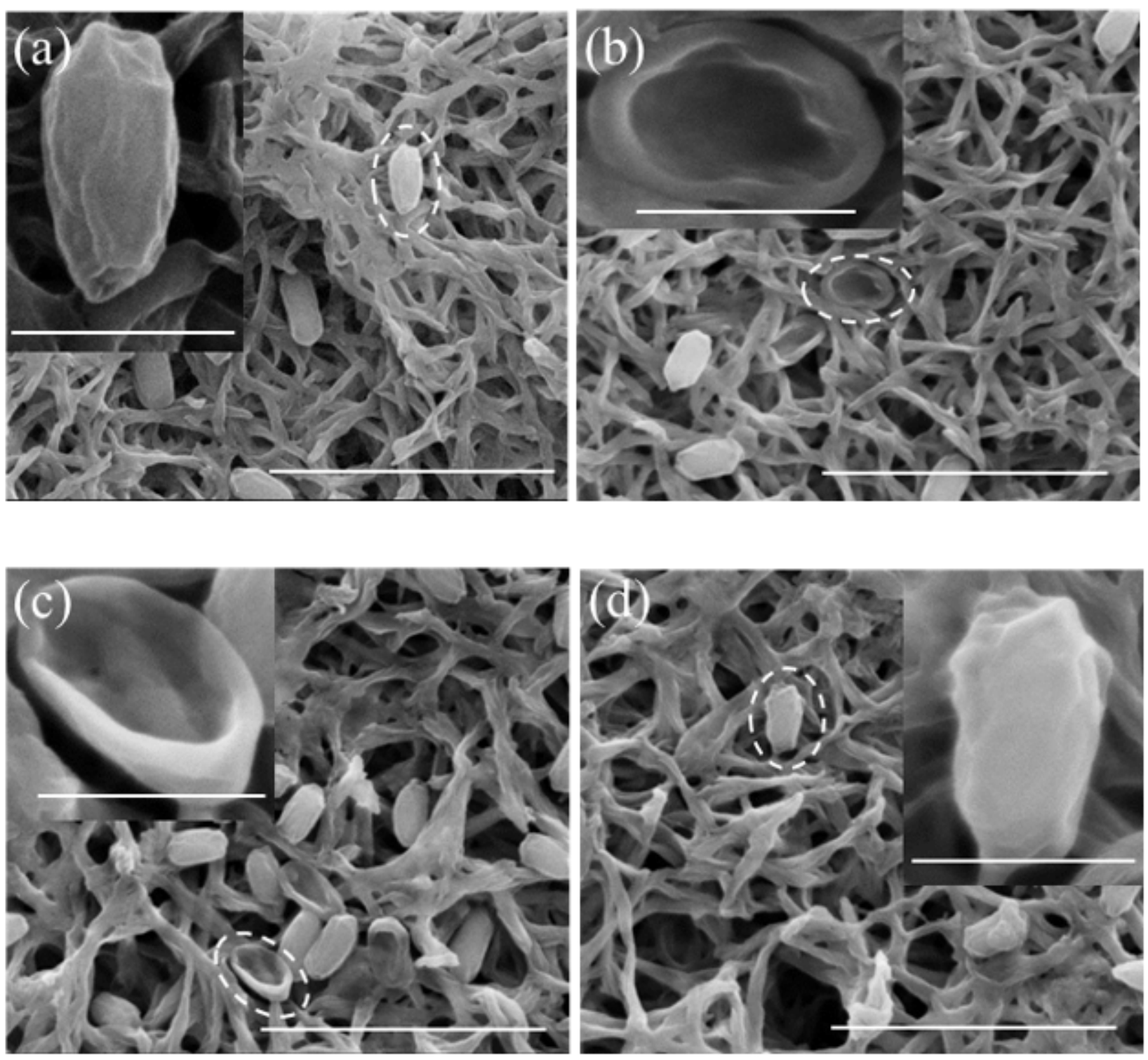

Figure 2

SEM images of PEF-treated spores at $15 \mathrm{kV} \mathrm{cm}-1$. The scale bar of the figures and the panels is $5 \mu \mathrm{m}$ and $1 \mu \mathrm{m}$ respectively. (a) Control, (b) 50 pulses in DI water, (c) 1 pulse in saline and (d) 50 pulses in saline. 


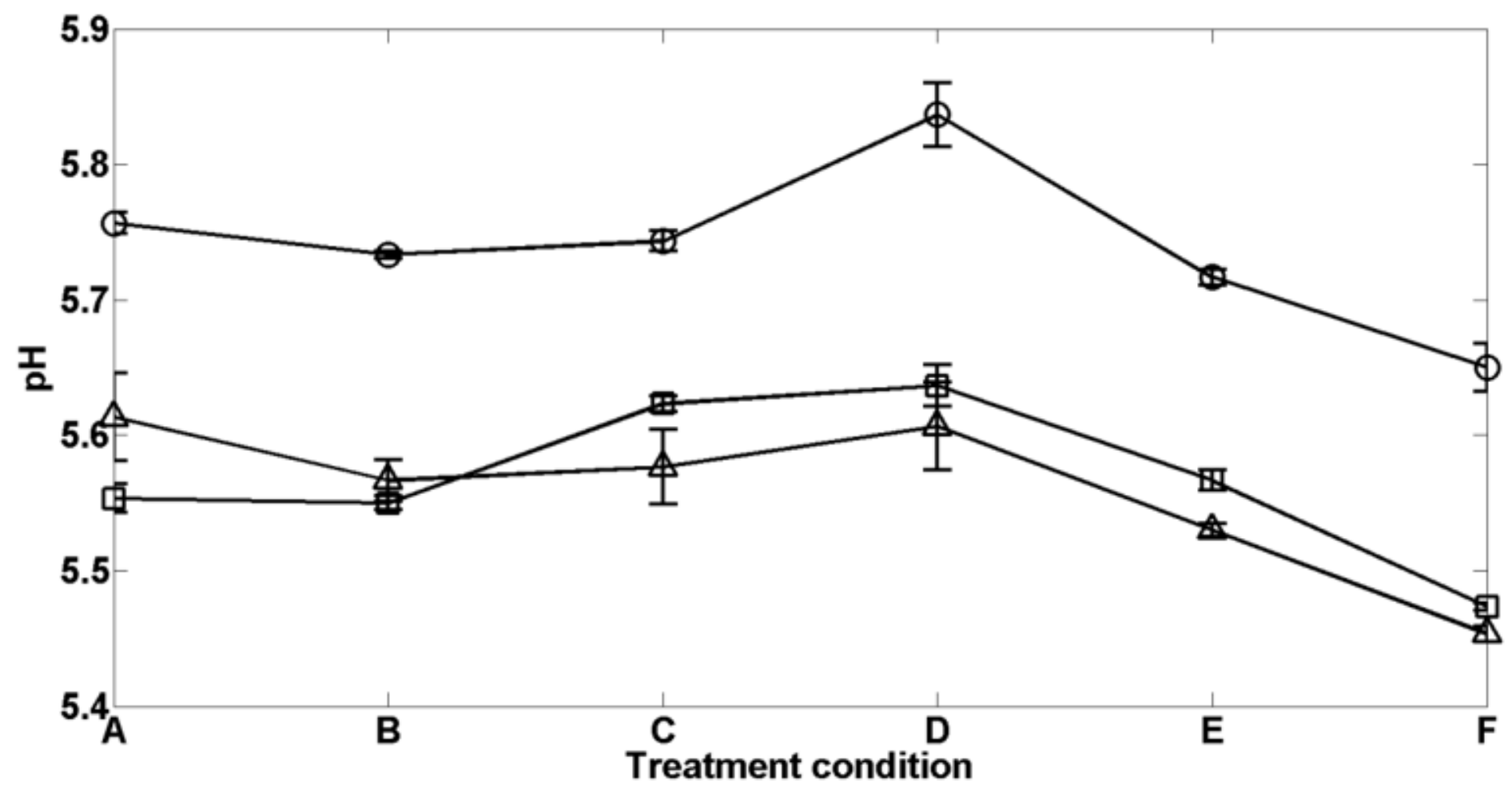

Figure 3

$\mathrm{pH}$ measurement of PEF-treated spores with treatment conditions of $15 \mathrm{kV} \mathrm{cm}-1$ in DI water and saline at three different concentrations: $(\triangle) 2 \times 107,(\triangle) 2 \times 105$ and $(\square) 2 \times 103$. (A) Control in DI water, (B) Control in saline, (C) 1 pulse in DI water, (D) 50 pulses in DI water, (E) 1 pulse in saline, (F) 50 pulses in saline. 

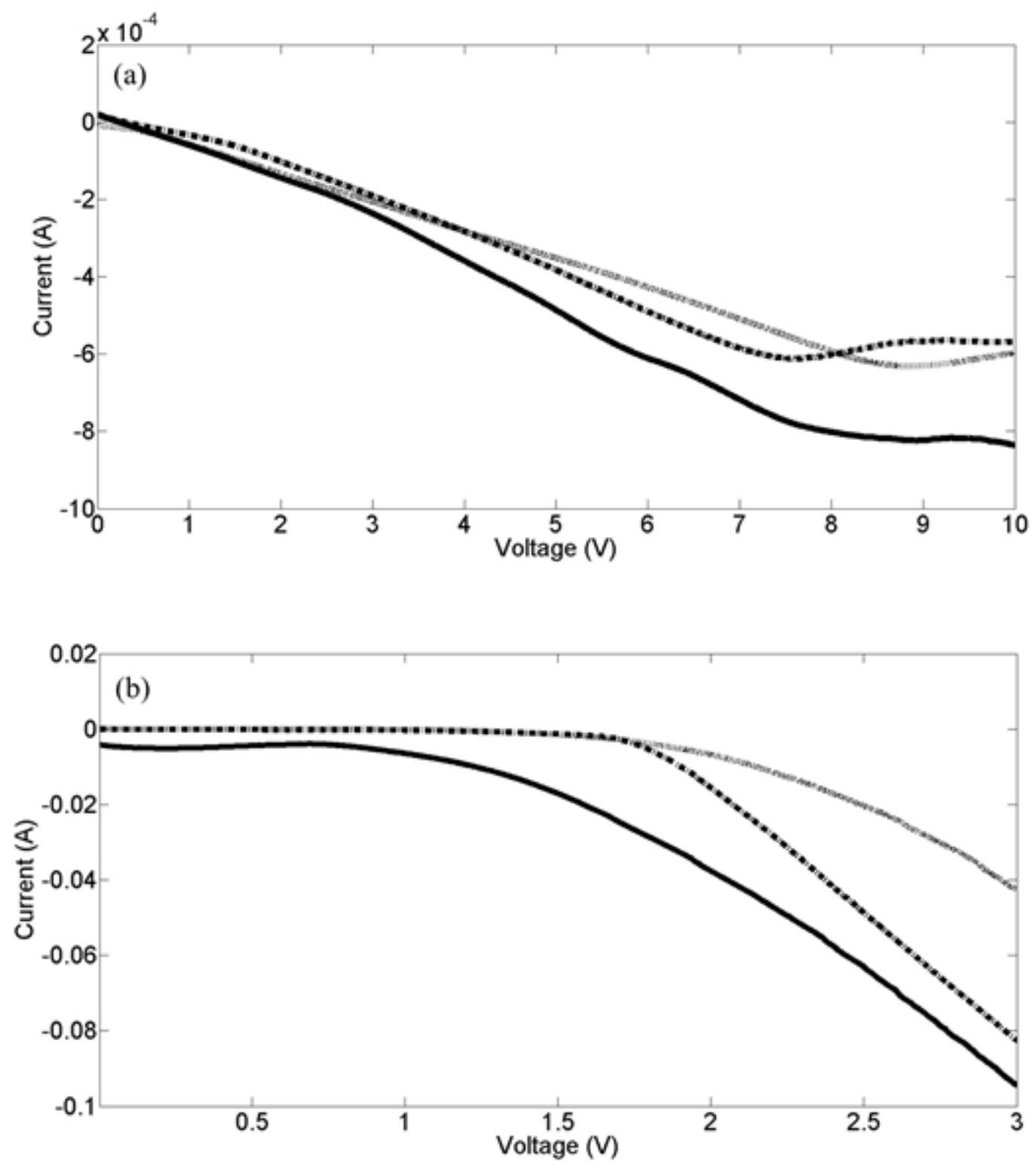

\section{Figure 4}

Linear sweep voltammetry measurement of PEF-treated spores in DI water (a) and in saline (b). (dashed line) Non-PEF treatment, (dotted line) $15 \mathrm{kV} \mathrm{cm}-1,1$ pulse and (solid line) $15 \mathrm{kV} \mathrm{cm}-1,50$ pulses. 


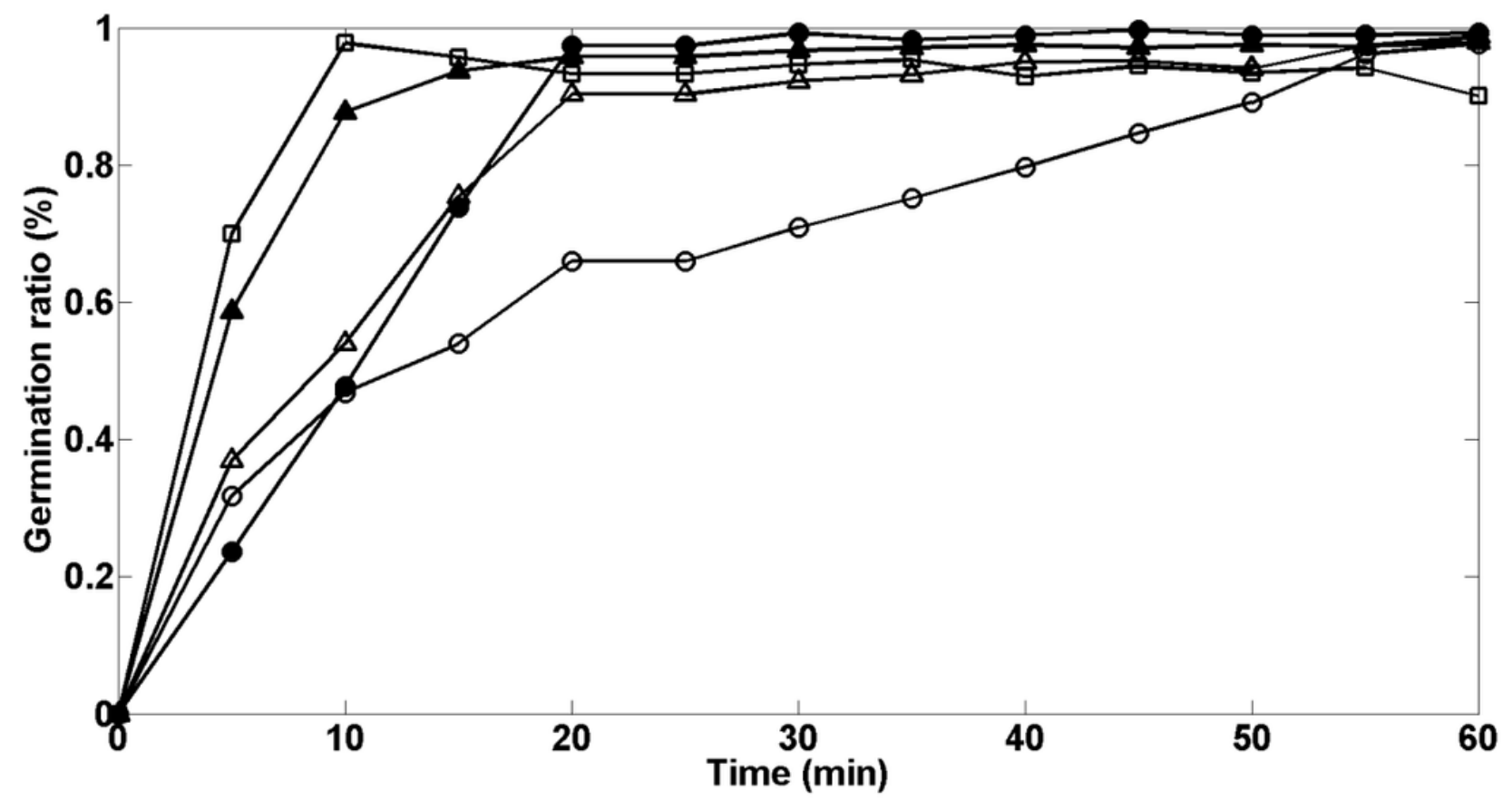

Figure 5

Germination kinetics monitored by phase-contrast microscopy. Germination ratio of PEF-treated spores and control during $60 \mathrm{~min}$. (๑) Non-PEF treatment, $(\triangle) 7.5 \mathrm{kV} \mathrm{cm}-1,1$ pulse in saline, $(\square) 7.5 \mathrm{kV} \mathrm{cm}-1,50$ pulses in saline, () $15 \mathrm{kV} \mathrm{cm}-1,1$ pulse in saline and $(\mathbf{\Delta}) 15 \mathrm{kV} \mathrm{cm}-1,50$ pulses in saline.

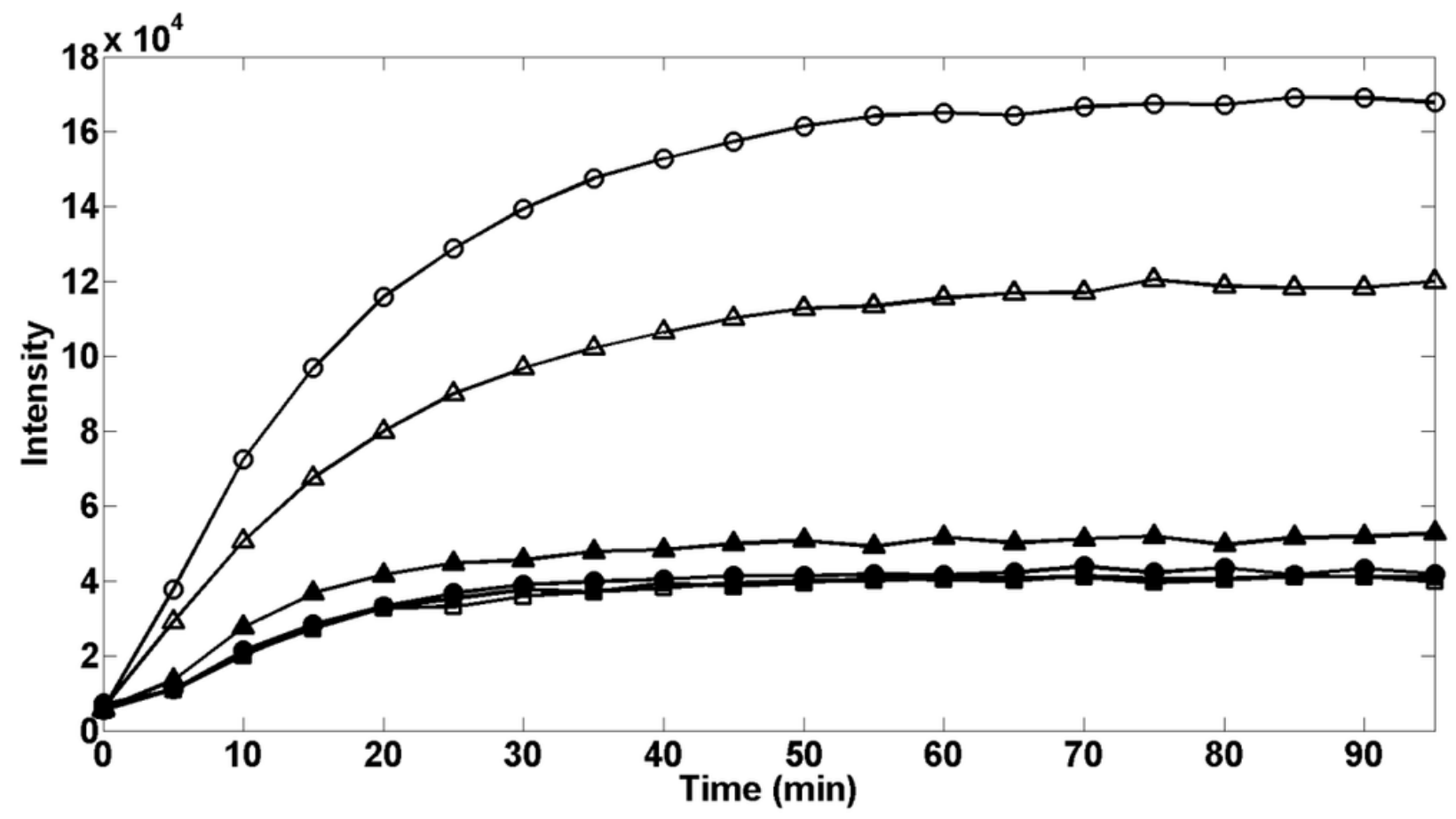

Figure 6

Germination kinetics monitored by Tb-DPA luminescence assay. DPA release kinetics during spore germination. ( $7.5 \mathrm{kV} \mathrm{cm}-1,1$ pulse in DI water, $(\triangle) 7.5 \mathrm{kV} \mathrm{cm}-1,50$ pulses in DI water, $(\square) 7.5 \mathrm{kV}$ cm-1, 


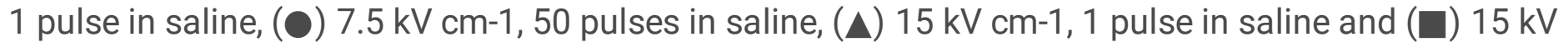
$\mathrm{cm}-1,50$ pulses in saline.

\section{Supplementary Files}

This is a list of supplementary files associated with this preprint. Click to download.

- SupplementaryMaterial.docx 